\title{
特集 計算機科学から生体膜研究へのアプローチ
}

\section{脂質膜の構造安定性と透過性の分子動力学 \\ シミュレーションによる予測}

\section{篠田 渉}

産業技術総合研究所計算科学研究部門 $\quad$ T305-8568 茨城県つくば市梅園1-1-1 中央第2

\section{Molecular Dynamics Study on Stability and Permeability of Lipid Membranes}

\begin{abstract}
Wataru Shinoda
Research Institute for Computational Sciences, National Institute of Advanced Industrial Science and Technology, Central 2, Umezono 1-1-1, Tsukuba, Ibaraki 305-8568, Japan
\end{abstract}

\begin{abstract}
A slight structural change in lipid molecules sometimes produces dramatic changes in the membrane properties such as structural stability and solute permeability. For example, archaeal lipids bearing ether-linked, highly branched hydrophobic chains form stabile bilayers with low permeability of ionic and nonionic solutes. Nowadays, it is possible to investigate the alteration of the membrane properties induced by a variation of the molecular structure of lipids by using molecular dynamics (MD) simulations. The approach will open a way to design a novel lipid, which should form a membrane with desirable physical properties on the purpose, based upon molecular simulations. In this review, we will introduce a few of our recent MD studies on the effect of chain branching and ether-linkage on the membrane properties.
\end{abstract}

Key words : archaeal lipid/structural stability / permeability/lipid membranes/ether-linkage/chain branching

\section{1.はじめに}

脂質膜の物理的な安定性や低分子やイオンの透 過性は, 膜を構成する脂質の分子構造に依存して 大きく変化する。この事実は合成脂質分子を用い 新しい機能性を持った脂質膜の創製に取り組む多 くの研究を動機づけており, バイオリアクタ・セ ンサなどのデバイスを構築しようとするバイオテ
クノロジー分野においても，近年，新規合成脂質 を使用した材料開発が盛んに進められている11. 苛酷な環境下（高温, 低 $\mathrm{pH}$, 高塩濃度など）で 棲息する古細菌は高い安定性と低い透過性を持つ 膜を有すると考えられており，この特性はデバイ スへの応用における要求性能と符合する。そのた め, 近年, 古細菌型合成脂質の開発がなされ, 実 際それらの膜が外部ストレスに対しても安定で, 
354 篠田：脂質膜の構造安定性と透過性の分子動力学シミュレーションによる予測

プロトンなどに対して低透過性を示すことが示さ れている2). 古細菌膜構成脂質の分子構造は, 1）疎水鎖が多くのメチル分岐を有し，2）疎水鎖 とグリセロールがエーテル結合によって結ばれ， しばしば 3）極性基を2つ持つ膜貫通型の脂質分 子が存在するという特徵を持つ。このような分子 構造の特徽は, 分子集合体である膜の安定性や透 過性と，分子論的にどのような相関を持つのであ ろうか? その知見は合成脂質の分子設計において 大変重要な情報である，分子構造をもとにモデル を組み立て, 統計力学的に分子集合体物性を解析 する分子シミュレーションは，これらの知見を与 えうる最も有効な研究ツールの一つであろう.

脂質膜の分子シミュレーション，中でも分子動 力学 (MD) シミュレーションが本格的に始めら れたのは 90 年代に入ってからであり，当初は DPPC二重層膜を対象とした方法論的な研究が主 流であった。脂質膜系のMDによる方法論的な枠 組みの完成と原子間相互作用力場の改良，さらに は汎用プログラムの普及やコンピュータ性能の向 上によって，90年代後半から急速にアプリケーシ ヨン研究が進み, 現在では様々な分子構造を持つ 脂質膜，イオンチャネルやポンプなどの膜タンパ ク質が介在する膜，コレステロールなどの添加物 を含む膜の物性研究がMDシミュレーションによ って報告されるまでになった ${ }^{3 \sim 5)}$. 本稿では，最 近, 我々が取り組んでいる古細菌型脂質膜のMD シミュレーションを例とし，計算科学を用いてど のような膜物性の解析が可能なのかについて紹介 したい.

\section{2. 古細菌型脂質膜のMD計算}

古細菌型脂質の分子構造の大きな特徵, (1)疎水 鎖の分岐，(2)エーテル結合，という分子構造変化 が膜物性に及ぼす影響をそれぞれ調べるため， 我々はまず極性基がホスホコリン基であるリン脂 質，ホスファチジルコリン（PC）を採用し，脂 質膜の中で最も物性研究の進んでいるジパルミト イルホスファチジルコリン（DPPC）を参照脂質 として選び，(1)分岐鎖を持つジフィタノイルPC
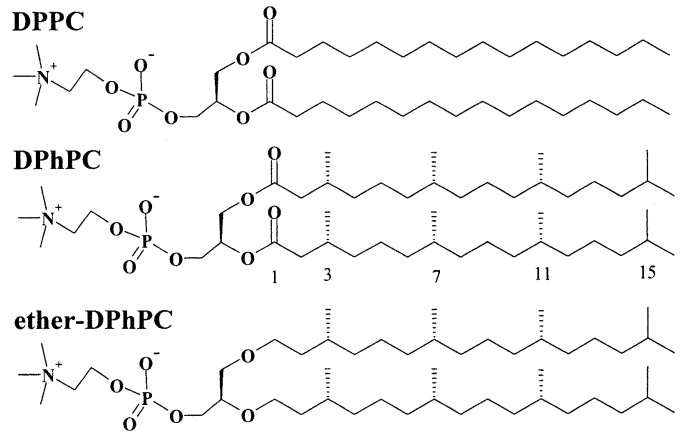

Fig. 1 Chemical structures of dipalmitoyl phosphatidylcholine (DPPC), diphytanoyl phosphatidylcholine (DPhPC), and diphytanyl phosphatidylcholine (ether-DPhPC).

(DPhPC), (2)さらにエーテル結合を持つジフィ タニルPC (ether-DPhPC) を採用し (Fig. 1)，そ れぞれの脂質が水中で形成する脂質膜のMDシミ ユレーションにより，これらの脂質膜の物性を比 較した. 膜のMD計算における方法論的な解説は 他に謴り6,7)，ここでは用いた計算条件を簡単に 述べる. 各システムは脂質 72 分子及び水 2,088 分 子で構成した，MD計算は温度・圧力一定条件で 行い，温度は323K（DPPC, DPhPC), $298 \mathrm{~K}$ (DPhPC, ether-DPhPC) で行い, 圧力はいずれの 場合も1気圧に設定した。 $1 \sim 3 \mathrm{~ns}$ の平衡化計算の 後，10〜25 nsの本計算をそれぞれのシステムで 行い, 構造や動的性質の解析を行った。

\section{3. 脂質膜の物性変化}

\section{1 疎水鎖の分岐の影響}

疎水鎖分岐の影響は，DPPCとDPhPC脂質二重 層膜の物性の比較から調べた. Fig. 1から分かる ように, $\mathrm{DPhPC}$ に $3,7,11,15$ の炭素の位置にメ チル分岐があり，その分岐によって主鎖の二面角 の状態に変化がもたらされる，直鎖のDPPCの場 合, その液晶相では疎水鎖中にgauche構造の二面 角が25-36\%程度現れることが実験からもMDから も報告されている ${ }^{8,9)}$. 分岐鎖の場合はメチル分 岐の隣接二面角がほぼ50\%近いgauche構造を持つ. これはメチル分岐の立体障害によってtrans構造 

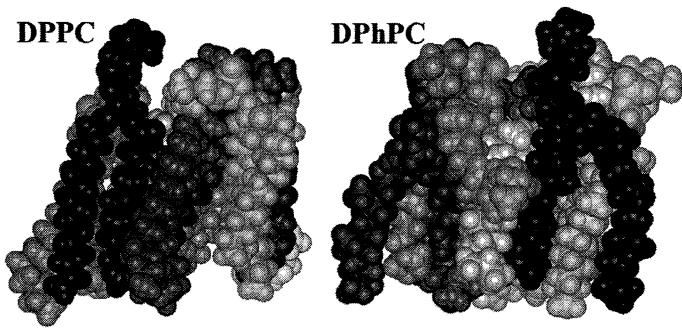

Fig. 2 Typical snapshot of the lipid membrane patches. Taken from Ref.10).

のgauche構造に対するエネルギー的な優位性が小 さくなり，熱ゆらぎによって容易にgauche構造に 転移するためである。主鎖にgauche構造が存在す ると，その位置で鎖は折れ曲がる。つまり DPhPCの疎水鎖は分岐炭素の位置で特異的に折 れ曲がり構造を持つ10). このコンフォメーション 変化が様々な物性変化の起源となっている.

DPPCなどの直鎖型脂質膜では，膜面内での隣 接疎水鎖間の配向の相関が強く, 遠方の踈水鎖に 比べ近接疎水鎖と, より平行に並ぶ傾向を持つ. これに対し分岐鎖を持つDPhPCでは，先述の踈 水鎖の折れ曲がり構造のため, 近接疎水鎖の平行 配列が困難となり，脂質鎖のパッキングが大きく 変化する ${ }^{11)}$. Fig. 2に各脂質膜の断片を切り出し たスナップショットを示す。図からDPPCでは特 に1分子内の 2 本の疎水鎖が平行に並ぶのに対し, $\mathrm{DPhPC}$ では隣接脂質の疎水鎖が2本の疎水鎖の間 に介在するような構造が多く見られるごとがわか る。このような分子間の疎水鎖同士の交差は，脂 質膜の構造的な安定性をもたらす原因であり，ま た疎水鎖の運動性を低下させている。実際に疎水 鎖内二面角のgauche-trans 異性化運動, 疎水鎖の 振り子運動 (wobbling in a cone) を観測すると, 分岐鎖におけるそれらの時定数はそれぞれ約 5 倍, 2倍と長くなっていることがわかった ${ }^{10)}$.さらに， $\mathrm{DPhPC}$ 脂質の側方拡散や回転運動なども2-3倍程 度，直鎖のDPPCに比べ遅くなっていることがわ かった11）(Table 1)。これらの計算值は実験值と およそ一致しているが，しばしば無視できない誤 差が見られる。その理由として，計算ではモデル
Table 1 Lateral diffusion coefficient, $D\left[\times 10^{-8} \mathrm{~cm}^{2} \mathrm{~s}^{-1}\right]$, rotational relaxation time, $\tau^{\text {rot }}[\mathrm{ns}]$, and relation times of the wobbling motion of the hydrophobic chain, $\tau$ wobbing [ns], and of the PN vector in the headgroup, $\tau^{P N}$ [ns].

\begin{tabular}{lrr}
\hline & \multicolumn{1}{l}{ DPPC } & \multicolumn{1}{l}{ DPhPC } \\
\hline$D_{\text {cal }}$ & $35.3 \pm 0.6$ & $13.7 \pm 0.5$ \\
$D_{\text {exp }}{ }^{a}$ & $20.7 \pm 2.8$ & $18.1 \pm 5.6^{\mathrm{b}}$ \\
$\tau^{\text {rot }}$ & $4.8 \pm 1.2$ & $10.2 \pm 2.5$ \\
$\tau_{\text {cal }}^{\text {wobbling }}$ & $1.7 \pm 0.3$ & $3.3 \pm 0.3$ \\
$\tau_{\text {exp }}^{\text {wobbling a }}$ & $1.79 \pm 0.91$ & $2.27 \pm 1.14^{\mathrm{b}}$ \\
$\tau^{P N}$ & $0.53 \pm 0.1$ & $0.45 \pm 0.1$ \\
\hline
\end{tabular}

a The experimental data are taken from 2).

b The data were obtained for egg yolk phosphatidylcholine bilayers.

の精度や統計誤差が考えられ，また実験における 蛍光プローブ使用に由来する䛊差などが影響す る。しかし，ここでの結果は定性的な議論におい ては十分な精度を持つものと考えられる. 疎水鎖 の分岐によってDPhPCの運動性がすべて下がる 訳ではなく例外がある。それは極性基の回転運動 である、PC分子内のリン酸基（P）からコリン四 級アミノ基（N) にかけて大きな双極子があるが， そのPN双極子の回転運動を調べると，DPhPCの 方がやや短い回転緩和時間を示した (Table 1) ${ }^{11)}$. 分岐の存在による一連の運動性の変化は, 脂質膜 にコレステロールを添加した際の変化と類似して いる。コレステロールを脂質膜に添加すると，脂 質膜の秩序度が高くなり運動性を下げるが，極性 基の運動だけはやや促進される。の原因はコレ ステロール添加によって膜内の脂質間距離が大き くなり，極性基間の双極子一双極子相互作用が低 下するためである12,13). 分岐鎖のDPhPCにおい ても，膜面積はDPPCに比べ15\%程度大きく (DPPC : $62 \AA^{2}$, DPhPC : $77 \AA^{2}$ ), 同様の議論が成 
り立つ。

次に膜中の物質透過に関する解析について述べ る。親水性分子，例えば水分子が脂質膜を横切る 透過現象は，分子レベルでは非常に稀にしか起こ らない事象であるため，現在の限界である10～ $100 \mathrm{~ns}$ の MD計算では, 直接その現象を捉えるこ とは困難である。しかし，そのような現象に関係 する物理量, ここでは透過係数，を計算する手法 はすでに開発されている，Marrinkらによると16), 透過が拡散律速において起こると仮定すると，透 過係数 $(P)$ が次式によって算出される.

$$
1 / P=\int_{z_{1}}^{z_{2}} \frac{\exp (\Delta G(z) / k T)}{D_{z}(z)} d z
$$

この式では膜透過における自由エネルギー変化 $\Delta G$ および透過分子の拡散係数 $D_{z}$ の計算が必要 である. $k$ はボルツマン定数, $T$ は絶対温度, $z$ は膜面垂直軸で，積分の端点は膜の中と外にそれ ぞれ取る。自由エネルギー $\Delta G$ は，分子シミュレ ーションによって得られる最も重要な物理量の一 つで，一般に計算が容易でなく，これまで様々な サンプリング手法が開発されている14). 各手法は 原理的には同じ自由エネルギーを計算するもので あるが，対象によって各アルゴリズムの計算值の 収束性や計算効率は大きく異なる。ここでは, 空 隙に対してのみサンプリングする粒子挿入法 (Cavity insertion method) ${ }^{15)}$, 存在確率分布法 (Probability ratio method) ${ }^{16)}$, 及び熱力学的積分 法 (Thermodynamic integration) の組み合わせ によって，効率的かつ高精度で求められた水分子 の膜を横切る自由エネルギープロフィールを Fig.3aに与える。この場合，水相を自由エネルギ 一計算 (計算されるのは自由エネルギー差である) の原点にとっており, 脂質膜内部で水分子の熱力 学的な安定性が低くなることがわかる.DPPC及 びDPhPC膜いずれの場合も, 水分子に対して膜 内部に㧍よそ $6 \mathrm{kcal} / \mathrm{mol}$ 程度の自由エネルギーバ リアを示した。両者の差はほとんど統計誤差内で しかないが，透過が遅いと考えられている DPhPC膜の方がむしろ, ややバリアが低いとい

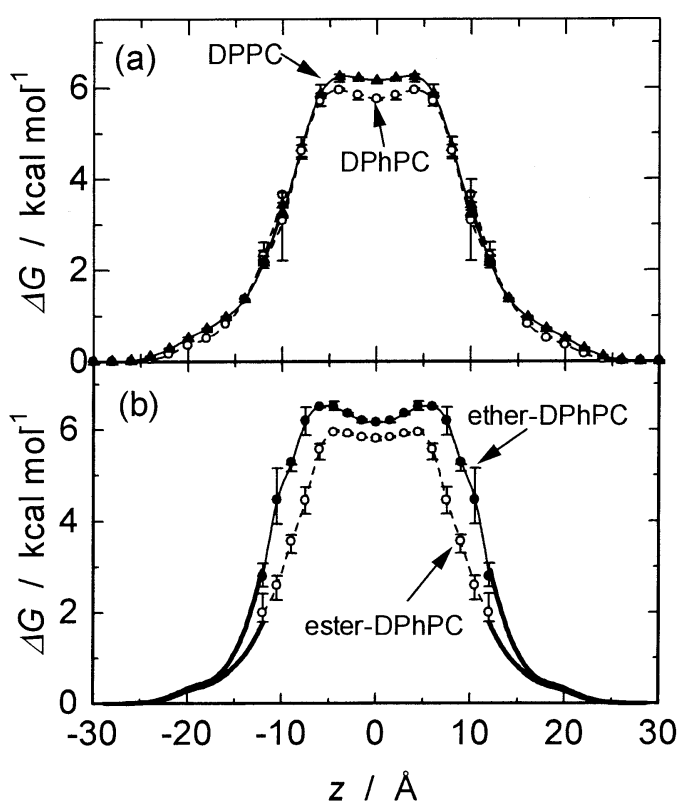

Fig. 3 Free energy profiles of water molecule along the bilayer normal, $z$. (a) DPPC and DPhPC bilayers at $323 \mathrm{~K}$. (b) ether- and ester-DPhPC at $298 \mathrm{~K}$. The origin of the $z$-axis was taken at the bilayer center.

う予測に反する結果となった，結局，DPhPCに 拉ける水の透過係数の低下は, 膜中での水分子の 易動度の低下が原因であることがわかり，水分子 の局所拡散係数 $D_{z}$ を計算し，（1）式を用いて透 過係数を計算すると, DPPC膜で約 $1.6 \times 10^{-2}$ $\mathrm{cm} / \mathrm{s} ， \mathrm{DPhPC}$ 膜で約 $1.1 \times 10^{-2} \mathrm{~cm} / \mathrm{s}$ となり，疎 水鎖分岐によって水の透過係数が 3 割程度低下す ることが予測された ${ }^{17)}$. 実験デー夕は数多く存在 するが, 透過係数の值は実験条件の詳細に非常に 敏感で定量的な議論が難しく $10^{-2} \sim 10^{-4} \mathrm{~cm} / \mathrm{s}$ の範 囲で報告されている18)。水の透過係数を同じ条件 で調べた研究例として, 直鎖脂質からなる大腸菌 膜とDPhPC膜では透過係数がそれぞれ $4.9 \times 10^{-3}$ $\mathrm{cm} / \mathrm{s}, 4.29 \times 10^{-3} \mathrm{~cm} / \mathrm{s}$ とな, 分岐によって透 過係数が約 2 割下がることが観測されており ${ }^{19)}$, $\mathrm{MD}$ 計算の值と定性的な変化量はおよそ一致して いる.

上で透過係数の計算を行ったが, 透過現象のメ 

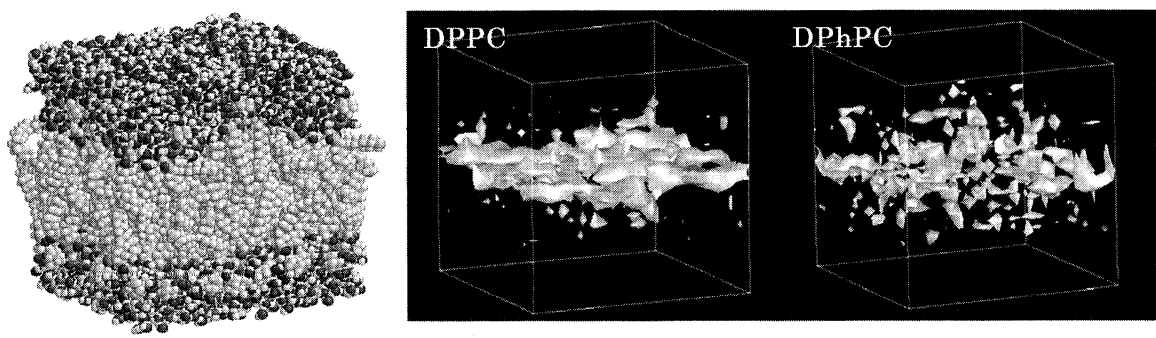

Fig. 4 Cavity distribution in the lipid bilayers averaged over $1.5 \mathrm{~ns}$ MD trajectories. The isosurface shows the probability of cavity formation at a level of 0.15 . As a guide for the eye, a snapshot of the DPPC system is also drawn with the same box size.

カニズムについての情報はほとんど得られていな い. 得られている原子座標から何かヒントをつか むことができないであろうか? 水分子の易動度や 疎水性鎖の運動性の解析から, それらの間の時定 数は少なくとも 1 桁違うことが分かってきた。例 えばバルク水中の隣接水分子の交換は疎水鎖の二 面角異性化速度に比べて 1 桁以上も短い時間で起 こる.このことから水分子が膜中を横切る際には, 脂質分子はほとんど止まっているように見え，脂 質膜中にできた空隙に沿って水分子が移動すると いう推測が成り立つであろう。この仮定に基づき 膜中の空隙分布を調べた。その結果, Fig. 4に見 られるように, DPPCでは膜中央のスリップ面を 中心に大きな空隙分布が存在するのに対し, DPhPC膜では小さな空隙が離散的に分布してい ることが判明した。この差は定性的にしか意味を 持たないが, DPhPC中を移動する水分子は空隙 間をジャンプするような運動を示し，膜の垂直方 向だけでなく側方への拡散も拘束を受けることが 予測される。 また，分布の差から水分子の膜内部 での会合（クラスター化）も分岐によって制限さ れることも予測され，水分子間の水素結合網をプ ロトンが透過するというプロトンワイヤー仮説20) に基づくと，プロトンの透過係数も脂質疎水鎖の 分岐によって大きく減少するはずであり，これは 実験とよく対応する. 水分子の脂質膜内部での運 動については，実際に水分子を膜中に配置した初 期構造からのMD計算を何度も繰り返し，水分子 の膜内での運動を観測することで，上記の描像が
正しいことを支持する結果を得ている17).

\section{2 エーテル結合の影響}

エステルをエーテルに置換することによって， 実験からも示されているように, 静電ポテンシャ ル(膜電位) が約半分程度まで低下した ${ }^{21)}$ 。また エステル基とエーテル基の比較では, 前者が水分 子とより強く会合することがわかり, etherDPhPCではグリセロール付近への水分子の浸透 が減少した。また，水分子の膜を横切る自由工ネ ルギープロフィールに拉いてもはっきりとした違 いが見られた。 ether-DPhPCはエステル型の DPhPCよりも膜内部で常に高い自由エネルギー 障壁を示している (Fig. 3b). エーテル/エステル 結合が存在する領域は拉よそ $|z|=14 \sim 15 \AA$ で あるが，膜疎水鎖領域にわたってエーテル型脂質 膜がより高いエネルギー障壁を示した。これはカ ルボニル双極子の存在が膜中での水分子の静電的 な安定性に寄与していることを示している。すな わち，エステルからエーテル結合に置換すること によって, 膜内部への水分子 (また極性分子) の 浸入はより阻害されるという結果が得られ, 疎水 鎖の分岐だけでなく, エーテル結合という古細菌 脂質の構造の特徵は, 膜の透過性の低下に重要な 寄与をしていることが分かった。

\section{4. おわりに}

古細菌膜脂質の分子構造の特徵である疎水鎖の 
分岐やエーテル結合による膜物性の変化を, MD シミュレーションによって解析した研究を紹介し た. MD計算によって様々な情報を得る可能性を 示したが，実験情報なしに，予測的にシミュレー ションが使えることを示すには至っていない.し かし，これまでの経験上，定性的な物性变化の予 測は可能であると考えており，現在，極性基を 2 つ持つテトラエーテル型脂質膜ではMDによる物 性予測を実験に先駆けて行っている。しかしこれ は分子シミュレーションが完成の域に達している ことを決して意味せず，まだその適用範囲は限定 的である。今後の発展には, 定量性に向けてのモ デルの精度向上やさらなる計算効率の向上が必要 で，その適用可能性を広げ，予測技術としての価 值を高める努力が要求される. ドラッグデザイン の分野で行われているように，実際に新規脂質を 合成する前にいくつか候補を精度よくスクリーニ ングすることが分子集合体設計においても近い将 来現実のものとなると期待する.

\section{謝辞}

本研究のほとんどは, 産業技術総合研究所三 上益弘博士，馬場照彦博士，羽藤正勝博士，篠田 恵子博士との共同研究であり，これらの方々に感 謝したい。また本研究は, 文部科学省 超高速コ ンピュータ網形成プロジェクト NAREGI ナノサ イエンス実証研究によってコンピュータリソー ス及び研究資金の援助を受けている.

\section{文献}

1）馬場照彦：膜, 27 303-309（2002）

2) Baba $\mathrm{T}$, Minamikawa $\mathrm{H}$, Hato M, Handa $\mathrm{T}$ : Biophys. J., 81 3377-3386 (2001)

3) Scott HL : Curr. Opin. Struct. Biol., 12 495-502 (2002)

4) Saiz L, Klein ML : Acc. Chem. Res., 35 482-489 (2002)

5) Tieleman DP, Marrink SJ, Berendsen HJC : Biochim. Biophys. Acta, 1331 235-270 (1997)

6）篠田 渉, 岡崎 進 : Electrochemistry, 68 129-133 (2000)

7）岡崎 進: 生体系のコンピュータ・シミュレーショ ン,化学同人, pp.168-177（2002）
8) Mendelsohn R, Davies MA, Brauner JW, Schuster HF, Dluhy RA : Biochemistry, 28 8934-8939 (1989); Pink DA, Green TJ, Chapman D : Biochemistry, 19 349-356 (1980); Seelig J, Seelig A : Q. Rev. Biophys., 13 19-61 (1980)

9) Shinoda W, Namiki N, Okazaki S : J. Chem. Phys., 106 5731-5743 (1997)

10) Shinoda $W$, Mikami M, Baba T, Hato M : J. Phys.Chem. B, 107 14030-14035 (2003)

11) Shinoda $W$, Mikami M, Baba $T$, Hato $M$ : Chem. Phys. Lett., 390 35-40 (2004)

12) Davis JH : Biochim. Biophys. Acta, 737 117-171 (1983)

13) Saito $H$, Araiso $T$, Shirahama $H$, Koyama $T: J$. Biochem., 109 559-565 (1991)

14) Frenkel D, Smit B : "Understanding of Molecular Simulation" 2nd. Ed., Academic Press, San Diego (2002)

15) Jedlovszky P, Mezei M : J. Am. Chem. Soc., 122 5125-5131 (2000)

16) Marrink SJ, Berendsen HJC :J. Phys. Chem., 984155 (1994)

17) Shinoda $W$, Mikami M, Baba T, Hato M : J. Phys. Chem. B, 108 9346-9356 (2004)

18) Disalvo EA, Simon SA: "Permeability and Stability of Lipid Bilayers" CRC Press, Boca Raton, FL (1995) ,

19) Mathai JC, Sprott GD, Zeidel ML: J. Biol. Chem., 276 27266 (2001)

20) Nagle JF : J. Bioenerg. Biomembr., 19 413-426 (1987)

21) Gawrisch K, Ruston D, Zimmerberg J, Parsegian VA, Rand RP, Fuller N : Biophys. J., 61 1213-1223 (1992)

22) Shinoda K, Shinoda W, Baba T, Mikami M: J. Chem. Phys. 1219648 (2004)

（受付2004年9月27日 掲載決定9月 30 日）

\section{著者略歴}

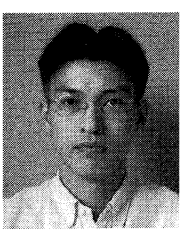

篠田 渉（しのだ わたる）

1993年 同志社大学工学部卒業

1998年 東京工業大学総合理工学 研究科博士課程修了

1998年 三菱化学株式会社入社

2000年 工業技術院 物質工学工

業技術研究所 入所

2001年4月1日 組織改編により 産業技術総合研究所 入所 現在 計算科学研究部門 在職中 